\title{
Amla as a Potential Substrate for Production of Probiotic Drink
}

\author{
Namesha Dulari Wijemanna and Usha Ravindra*
}

\begin{abstract}
Department of Food of science and Nutrition, University of Agricultural Sciences (UAS), GKVK, Bangalore-560065, Karnataka, India
\end{abstract}

*Corresponding author

\begin{tabular}{|l|}
\hline K e y w o r d s \\
$\begin{array}{l}\text { Amla, Saccharomyces } \\
\text { boulardii, Lactobacillus } \\
\text { acidophilus, } \\
\text { Probiotication }\end{array}$ \\
\hline Article Info \\
\hline $\begin{array}{l}\text { Accepted: } \\
18 \text { August } 2018 \\
\text { Available Online: } \\
10 \text { September } 2018\end{array}$ \\
\hline
\end{tabular}

A B S T R A C T
This study intended to examine the growth and stability of Saccharomyces boulardii and Lactobacillus acidophilus in amla drink with the aim of formulation of probiotic drink and to analyze the nutritive value, sensory qualities and shelf life of the product. S. boulardii CNCM 1-745 and L. acidophilus MCC10307 were capable of growing in 15 per cent amla drink at natural $\mathrm{pH}, 30^{\circ} \mathrm{C}$ with $22^{\circ} \mathrm{Brix}$ and 5 per cent honey. Optimum fermentation time at which the highest population was observed (8-10 log CFU/ml), for $S$. boulardii CNCM 1-745 was $35 \mathrm{hr}$ while $L$. acidophilus MCC10307, it was $64 \mathrm{hr}$. The sensory scores for fermented drinks were significantly $(\mathrm{P} \leq 0.05)$ lesser than the unfermented drink. In order to enhance the sensory qualities by reducing fermentation time while maintaining the highest population, initial $\mathrm{pH}$ and total soluble solids were adjusted and L. acidophilus (nu-trish LA-5) was used to replace L. acidophilus MCC 10307. With these modifications, amla drink with $3 \mathrm{hr}$ of fermentation provided better sensory qualities with required cell population and $97-108 \mu \mathrm{g} / \mathrm{ml}$ of ascorbic acid and $937.5 \mu \mathrm{g} / \mathrm{ml}$ of antioxidant potential. With the consideration to both population and sensory qualities, amla drink with $S$. boulardii CNCM 1-745 could be stored at refrigerated conditions $\left(4^{\circ} \mathrm{C}\right)$ for 30 days while L. acidophilus (nu-trish LA-5) could be stored for 12 days.

\section{Introduction}

Food with required population of beneficial microorganisms in human health is known as probiotic food which is gaining a growing public awareness as a functional food recently. The term probiotic is defined as live microorganisms which can accord several health benefits beyond inherent general nutrition when access into the body in adequate amount (Anon, 2001). According to findings, to be a probiotic product, it should contain a minimum number of probiotic population ranged from $10^{5}$ to $10^{6} \mathrm{CFU} / \mathrm{ml}$ or gram of the product (Vasudha and Mishra, 2013). Many authors suggested that ingestion of $10^{7}-10^{10}$ viable cells in a day could sufficiently promote the human health such as supplementation of food with probiotic is able to enhance several indices of acquired and natural immunity, probiotic treatment is an effective dietary means of averting or limiting diarrhoea and other stomach problems in human. Probiotics also can fight against pathogens like Helicobacter pylori, associated with the development of gastric cancer, peptic ulcers and chronic gastritis. Probiotics could 
protect against allergies, it can increase natural killer cell activity and probiotic consumption may also have potential effects on delayed tumour development (Matsuzaki and Chin, 2000; Oxman et al., 2001; Reid and Bruce, 2001).

Traditionally, probiotics have been added to yoghurt and other fermented dairy products since milk is the ideal source for probiotics growth. However, in recent years, a growing demand for non-dairy probiotic products comes due to several drawbacks related to probiotic foods based on dairy including lactose intolerance, high cholesterol content, vegetarianism, milk allergy and other factors (Priya and Khatkar, 2012). These facts have led to development of non-dairy probiotic products from various food matrices and also fruit based source would be a better option due to highly nutritive value of fruit itself.

Amla fruit is widely used as medicine as alone or in combination with other plants to treat common cold and fever, as a diuretic, laxative, liver tonic, refrigerant, stomachic, restorative, anti-pyretic, hair tonic; to prevent ulcer and dyspepsia (Priya and Khatkar, 2012). Modern scientists have studied amla's unique nutrient blend proved to have positive influences on everything from metabolic syndrome and blood flow to anti-aging processes. Pharmacological research reports on amla reveal its analgesic, anti-tussive, antiatherogenic, adaptogenic; cardio, gastro, nephron, neuroprotective and anticancer properties (Sharma et al., 2004; Nosal et al., 2003; Santoshkumar et al., 2013). Amla is also reported to possess chemopreventive, radio, and immunomodulatory, free radical scavenging, antioxidant, anti-inflammatory, anti-mutagenic activities (Baliga et al., 2013). These properties are efficacious in the prevention and treatment of various diseases like cancer, atherosclerosis, diabetes, peptic ulcer, anaemia, liver and heart diseases and various other disorders (Muruganandam et al., 2002).

Amla is highly nutritious and is one of the richest sources of vitamin-C $(600 \mathrm{mg} / 100 \mathrm{~g})$ and minerals $(50 \mathrm{mg} / 100 \mathrm{~g}) \cdot \mathrm{pH}$ of fruit is normally 3.0 to 4.0 (Zhang et al., 2003; Gopalan et al., 2010). It contains several phyto chemical constituents like tannins, alkaloids and phenols (Srivasuki, 2012). Amla fruit, owing to its high acidity and astringent taste, are not palatable and hence not suitable for direct consumption. It is consumed mainly in the processed form. Amla extracts are used in various food and beverage preparations such as nutritional bars, jams, yoghurts and dietary supplements.

The potential for amla extract as a food ingredient is increasing substantially, owing to the growing global nutraceuticals and functional food market. Increase in the demand of health drinks has given road for the development of various value-added beverages (Jain and Khurdiya, 2004). Hence, present study was carried to examine the growth of Saccharomyces boulardii and Lactobacillus acidophilus in amla drink with the aim of formulation of probiotic amla drink.

\section{Materials and Methods}

\section{Procurement of samples}

Commercially available fresh amla, sugar, honey and other ingredients for fruit drink were purchased from local market of Bangalore city, India. Saccharomyces boulardii CNCM 1-745 and Lactobacillus acidophilus MCC 10307 were purchased from local medical shop while Lactobacillus acidophilus (nu-trish LA-5) was from M/s CHR HANSEN Denmark, procured from CHR HANSEN India Pvt. Ltd. Mumbai were used for the fermentation. 


\section{Formulation of amla drink}

Amla fruit was steam blanched and seeds were separated. It was blended and juice was obtained. Different concentrations $(10 \%, 20 \%$, $30 \%$ and $40 \%$ ) of amla drink were prepared by mixing different proportions of the extracted juice and water. Honey $(5 \% \mathrm{w} / \mathrm{v})$ was added to each drink with a pinch of salt. Total soluble solids of each drink was adjusted to $22^{\circ}$ Brix (Amaley et al., 2016) by adding sugar and yield was about $611 \mathrm{ml}$.

\section{Acceptability of amla drink}

Acceptability of formulated amla drinks was studied by evaluating their sensory characteristics. Sensory qualities namely appearance, sweetness, sourness, consistency, colour, flavour, aroma and overall quality were tested using semi-trained panel $(\mathrm{N}=22)$ and the panelists were asked to record their observations based on a 9-point hedonic scale (Tuorila et al., 2008). Out of four concentration variations, the most accepted variation was selected for carrying out the further fermentation process.

\section{Preparation of substrate media}

Formulated amla drink was used as a substrate media for fermentation drink at natural $\mathrm{pH}$, $22^{\circ}$ Brix with 5 per cent honey supplementation.

\section{Preparation of inoculum}

Lactobacillus acidophilus MCC 10307 was stored by sub-culturing every two weeks in de Man, Rogosa and Sharpe (MRS) agar. Saccharomyces boulardii CNCM 1-745 and Lactobacillus acidophilus (nu-trish LA-5) were stored in sachets and kept at $4^{\circ} \mathrm{C}$ in the refrigerator. About $25 \mathrm{ml}$ of pure amla juice was measured and $75 \mathrm{ml}$ of sterilized water was added into a sterilized conical flask and mixed well. Five grams of D- glucose $(5 \%)$ and honey $(5 \%)$ were added to flask. It was pasteurized at $62^{\circ} \mathrm{C}$ for $30 \mathrm{~min}$. Cultures were propagated in concentrated drink in aseptic condition. Prepared inoculums were kept at $30^{\circ} \mathrm{C}$ in the incubator for $24-36$ hours.

\section{Fermentation}

Experiment was carried out as batch fermentation (in flasks). Pasteurized amla drink was inoculated with a $10 \%(\mathrm{v} / \mathrm{v})$ of Saccharomyces boulardii CNCM 1-745 and Lactobacillus acidophilus MCC 10307 inoculums separately and incubated at $30^{\circ} \mathrm{C}$ for $72 \mathrm{hr}$ for fermentation. Samples were collected at different time intervals for the analysis.

\section{Effect of fermentation on microbial population}

A change in population of organisms in amla drink during fermentation was measured through plate count technique (Dimitroski et al., 2015) and microbial population was recorded in $\log \mathrm{CFU} / \mathrm{ml}$. Fermentation time which showed maximum population was considered as the optimum fermentation time in further processes. Change in TSS and $\mathrm{pH}$ during fermentation was determined in order to study metabolic activity of organisms in the drink (Priyanka, 2014).

\section{Effect of fermentation on sensory qualities}

Effect of fermentation on sensory qualities of amla drink was studied by evaluating sensory characteristics of fermented drinks (Tuorila et al., 2008).

\section{Nutrition analysis of probiotic amla drink}

Ascorbic acid content of unfermented and fermented amla drinks was analysed using spectrophotometer (Sadasivam and 
Manickam, 1997). Ferric reducing antioxidant potential (FRAP) of unfermented and fermented amla drinks was measured using spectrophotometer according to the method proposed by Benzie and Strain (1999) and results were reported as $\mu \mathrm{g}$ of ascorbic acid equivalents (AAE) per ml.

\section{Storage study of formulated probiotic fruit drinks}

Shelf life of formulated probiotic amla drinks was studied by evaluating sensory characteristics and survivability of population in the drinks during 30 days of storage period.

\section{Statistical analysis}

Statistical tools such as mean, standard deviation, cubic curve fit and ANOVA were used in the analysis and interpretation of experimental data. The results of effect of fermentation on microbial population were fitted to cubic curve since it was better fit for experimental data (Pereira et al., 2011). One way ANOVA was used to test the significance of experimental data from sensory evaluation (Dandin, 2010).

\section{Results and Discussion}

\section{Acceptability studies of amla drink}

The scores pertaining to sensory qualities of concentration variations of amla drink are presented in Table 1. Amla drink with 15 per cent concentration was recorded significant ( $\mathrm{P}$ $\leq 0.05$ ) highest overall acceptability score of 8.0 compared to other three variations with highest sensory scores for all the parameters (ranged between 7.9-8.3 out of 9) except for colour. Therefore, among four variations, 15 per cent amla drink was selected for further fermentation process. A similar findings were reported by Priya and Khatkar (2012) who studied sensory acceptability of laboratory prepared amla juice using 9-point hedonic scale and reported amla was awarded 6-7 score for all most all studied parameters except sourness and bitterness (sensory score 1-3) with overall acceptability of 6.8 . Similarly, amla and kinnow mandarin juice was blended in proportions viz., 0:100, 10:90, $20: 80,30: 70,40: 60$ and 50:50 to prepare ready-to-serve (RTS) beverages having 10 and 12 per cent TSS and 0.3 per cent acidity. The treatment involving blending of amla juice with kinnow mandarin juice in 40:60 proportion was found most suitable since it had maximum sensory qualities in terms of highest overall acceptance score (6.74/9.00) with bright yellow colour, pleasant aroma and taste (Jain and Meena, 2013).

Figure 1 and 2 depict the influence of fermentation time on population of Saccharomyces boulardii CNCM 1-745 and Lactobacillus acidophilus MCC10307 in amla drink respectively. Increment in viable cell of organisms during fermentation process indicates capability of growth and survival of organisms in the drink. Result shows that both the organisms were capable of growing in amla drink in natural $\mathrm{pH}$ level, at $30^{\circ} \mathrm{C}$ and $22^{\circ}$ Brix conditions with 5 per cent honey supplementation. The experimental data was statistically analyzed by fitting to the cubic model since cubic model was better fit for the data. F-test was used as significance criteria for the fitted model.

Fitted cubic model for Saccharomyces boulardii CNCM 1-745 is presented in Figure 1 which was built using Equations 1.

The model was statistically significant at 5 per cent level since the calculated F value (97.45) was higher than the table $F$ value. Good coefficients of determination was also obtained $\left(\mathrm{R}^{2}=0.987\right)$ which indicates the 98.7 per cent of the variation is explained by the model for time intervals. 
Population $(\log \mathrm{CFU} / \mathrm{ml})=5.868+0.258 \mathrm{t}-$ $0.005 \mathrm{t}^{2}+2.693 \mathrm{E}-5 \mathrm{t}^{3}(1)$

Where $\mathrm{t}$ is fermentation time $(\mathrm{h})$

Cubic curve showed (Figure 1) a fast growth of Saccharomyces boulardii CNCM 1-745 up to $35 \mathrm{hr}$ of fermentation and the population increased from 5.85 to $10.03 \mathrm{log} \mathrm{CFU} / \mathrm{ml}$. At $35 \mathrm{hr}$, it showed the peak level of population and after that gradual decreased was observed. It may be due to either depletion of one or more essential nutrients or the accumulation of toxic by-products of growth (Duygu, 2004).

Even though Saccharomyces boulardii CNCM 1-745 could be able to maintain more than 9.0 $\log \mathrm{CFU} / \mathrm{ml}$ population upto $64 \mathrm{hr}$ of fermentation time, $35 \mathrm{hr}$ was the ideal fermentation time for amla drink with highest computed population $10.03 \log \mathrm{CFU} / \mathrm{ml}$. Because extended fermentation time could affect to the sensory qualities and commercial value. Chiang et al., (2006) and Ganzle et al., (2007) also observed similar behaviour of different microorganisms in different fermentation media.

Cubic fit for Lactobacillus acidophilus MCC10307 was built using Equations 2 (Figure 2). The model was statistically significant at 5 per cent level since the calculated $F$ value (74.5) was higher than the table $F$ value. Good coefficients of determination was also obtained $\left(\mathrm{R}^{2}=0.982\right)$ which indicates the 98.2 per cent of the variation is explained by the model for time intervals.

Population $(\log \mathrm{CFU} / \mathrm{ml})=6.340+0.048 \mathrm{t}+$ 4.072 E- $4 \mathrm{t}^{2}-8.582 \mathrm{E}-6 \mathrm{t}^{3}(2)$

Where $t$ is fermentation time (h)

Cubic curve showed a fast growth of Lactobacillus acidophilus MCC10307 upto 64 $\mathrm{hr}$ of fermentation and the population increased upto $8.83 \log \mathrm{CFU} / \mathrm{ml}$. At $64 \mathrm{hr}$ of fermentation, it showed the peak growth and after that population showed a decreasing trend. Therefore, $64 \mathrm{hr}$ was the ideal fermentation time for amla drink with highest computed population.

\section{Effect of fermentation time on total soluble solids (TSS)}

Change in TSS of amla drink due to fermentation is depicted in Figure 3. The initial TSS of amla drink at $22^{\circ}$ Brix was decreased upto 19.4 and $19.1^{\circ}$ Brix by Saccharomyces boulardii CNCM 1-745 and Lactobacillus acidophilus MCC10307 respectively within $72 \mathrm{hr}$ fermentation. This may be due to utilization of sugar by the microorganisms.

The changes in TSS in the developed fruit drinks proved the metabolic activity of organisms during fermentation. Initially TSS in the fruit drinks was adjusted to $22^{\circ} \mathrm{Brix}$ in order to supply the optimum growth condition for microorganisms. These results are supported by the findings of Amaley et al., (2016) who reported the optimum TSS level for microorganism's is $20-22^{\circ}$ Brix. Total soluble solids of a solution indicate sugar, mostly sucrose content in the solution. Decreased sugar content may be a reason for reduction in cell growth after a certain time of fermentation. According to Charalampopoulos et al., (2002), all microbes attained maximum cell populations when there is sufficient availability of total fermentable sugars in the fermentation media. Substrate deficiency in sugars contributed to growth limitation.

\section{Effect of fermentation time on pH}

$\mathrm{pH}$ plays a very important role in enhanced growth of the cells. Decrease in $\mathrm{pH}$ will affect the cell contents adversely. 
Table.1 Sensory scores for concentration variations of amla drink

\begin{tabular}{|l|c|c|c|c|c|c|c|c|}
\hline Treatments & Appearance & Sweetness & Sourness & Consistency & Colour & Flavour & Aroma & $\begin{array}{c}\text { Overall } \\
\text { quality }\end{array}$ \\
\hline $\mathbf{1 0 \%}$ & $7.2^{\mathrm{a}}$ & $7.0^{\mathrm{a}}$ & $6.6^{\mathrm{a}}$ & 7.3 & 7.5 & 6.5 & 7.8 & $6.9^{\mathrm{a}}$ \\
\hline $\mathbf{1 2 \%}$ & $8.0^{\mathrm{b}}$ & $7.3^{\mathrm{a}}$ & $7.0^{\mathrm{a}}$ & 7.9 & 7.8 & 7.5 & 8.0 & $7.3^{\mathrm{b}}$ \\
\hline $\mathbf{1 5 \%}$ & $8.3^{\mathrm{c}}$ & $8.1^{\mathrm{b}}$ & $7.9^{\mathrm{b}}$ & 8.1 & 8.2 & 8.2 & 8.0 & $8.0^{\mathrm{c}}$ \\
\hline $\mathbf{2 0 \%}$ & $7.7^{\mathrm{a}}$ & $6.8^{\mathrm{a}}$ & $6.5^{\mathrm{a}}$ & 7.4 & 8.4 & 6.5 & 7.7 & $6.8^{\mathrm{a}}$ \\
\hline Mean & 7.8 & 7.3 & 7.0 & 7.7 & 8.0 & 7.1 & 7.9 & 7.3 \\
\hline F value & $*$ & $*$ & $*$ & $\mathrm{NS}$ & NS & NS & NS & $*$ \\
\hline SEm \pm & 0.083 & 0.079 & 0.08 & 0.08 & 0.06 & 0.75 & 0.06 & 0.07 \\
\hline CD & 0.081 & 0.077 & 0.078 & - & - & - & - & 0.068 \\
\hline
\end{tabular}

Figures with the same superscript in a column indicates no significant difference at $\mathrm{P} \leq 0.05$

*Significant at $5 \%$ level

NS-Non-significant

Table.2 Sensory scores for fermented amla drink

\begin{tabular}{|l|c|c|c|c|c|c|c|c|}
\hline Treatments & Appearance & Sweetness & Sourness & Consistency & Colour & Flavour & Aroma & $\begin{array}{c}\text { Overall } \\
\text { quality }\end{array}$ \\
\hline $\begin{array}{l}\text { Before } \\
\text { fermentation }\end{array}$ & 8.3 & $8.1^{\mathrm{a}}$ & $7.9^{\mathrm{a}}$ & 8.1 & 8.2 & $8.2^{\mathrm{a}}$ & $8.0^{\mathrm{a}}$ & $8.1^{\mathrm{a}}$ \\
\hline L. acidophilus & 8.2 & $4.7^{\mathrm{b}}$ & $5.5^{\mathrm{b}}$ & 7.8 & 7.8 & $5.2^{\mathrm{b}}$ & $3.8^{\mathrm{b}}$ & $5.7^{\mathrm{b}}$ \\
\hline S. boulardii & 7.8 & $5.0^{\mathrm{b}}$ & $4.7^{\mathrm{b}}$ & 8.2 & 8.0 & $5.0^{\mathrm{b}}$ & $4.5^{\mathrm{b}}$ & $4.8^{\mathrm{b}}$ \\
\hline Mean & 8.1 & 5.9 & 6.0 & 8.2 & 8.0 & 6.0 & 5.4 & 6.2 \\
\hline F value & $\mathrm{NS}$ & $*$ & $*$ & $\mathrm{NS}$ & $\mathrm{NS}$ & $\mathrm{NS}$ & $*$ & $*$ \\
\hline SEm \pm & 0.41 & 1.09 & 0.96 & 0.16 & 0.11 & 1.03 & 1.29 & 0.98 \\
\hline CD & - & 0.71 & 0.63 & - & - & 0.67 & 0.84 & 0.64 \\
\hline
\end{tabular}

Figures with the same superscript in a column indicates no significant difference at $\mathrm{P} \leq 0.05$

*Significant at $5 \%$ level

NS-Non-significant

Table.3 Ascorbic acid and antioxidant potential of probiotic amla drink

\begin{tabular}{|l|c|c|}
\multicolumn{1}{|c|}{ Treatments } & Ascorbic acid $(\boldsymbol{\mu g} / \mathbf{m l})$ & Antioxidant potential $(\boldsymbol{\mu g} / \mathbf{m l})$ \\
\hline Before fermentation & 96 & 938 \\
\hline L. acidophilus & 109 & 938 \\
\hline S. boulardii & 98 & 938 \\
\hline Mean & 101 & 938 \\
\hline F value & $\mathrm{NS}$ & $\mathrm{NS}$ \\
\hline SEm \pm & 0.09 & 0.11 \\
\hline
\end{tabular}

NS-Non-significant 5\% level 
Table.4 Effect of storage time on population in probiotic amla drink

\begin{tabular}{|l|c|c|}
\hline $\begin{array}{l}\text { Storage period } \\
\text { (days) at } \mathbf{5} \pm \mathbf{1}^{\circ} \mathbf{C}\end{array}$ & $\begin{array}{c}\text { S. boulardii } \\
\text { Population } \\
(\mathbf{C F U} / \mathbf{m l})\end{array}$ & $\begin{array}{c}\text { L. acidophilus } \\
\text { Population } \\
(\mathbf{C F U} / \mathbf{m l})\end{array}$ \\
\hline Initial & $1.4 \times 10^{9}$ & $2.6 \times 10^{10}$ \\
\hline $\mathbf{6}$ & $2.9 \times 10^{9}$ & $6.9 \times 10^{10}$ \\
\hline $\mathbf{1 2}$ & $6.7 \times 10^{9}$ & $8.2 \times 10^{9}$ \\
\hline $\mathbf{1 8}$ & $3.3 \times 10^{9}$ & $5.5 \times 10^{5}$ \\
\hline $\mathbf{2 4}$ & $5.4 \times 10^{9}$ & $* *$ \\
\hline $\mathbf{3 0}$ & $2.3 \times 10^{9}$ & $* *$ \\
\hline Mean & $3.7 \times 10^{9}$ & $5.6 \times 10^{10}$ \\
\hline F value & $\mathrm{NS}$ & $\mathrm{NS}$ \\
\hline SEm \pm & $8.7 \times 10^{9}$ & $1.2 \times 10^{10}$ \\
\hline
\end{tabular}

**Due to loss of cell viability, discontinued the experiment NS-Non significant at $5 \%$ level

Fig.1 Effect of fermentation time on population of Saccharomyces boulardii CNCM 1-745 in amla drink

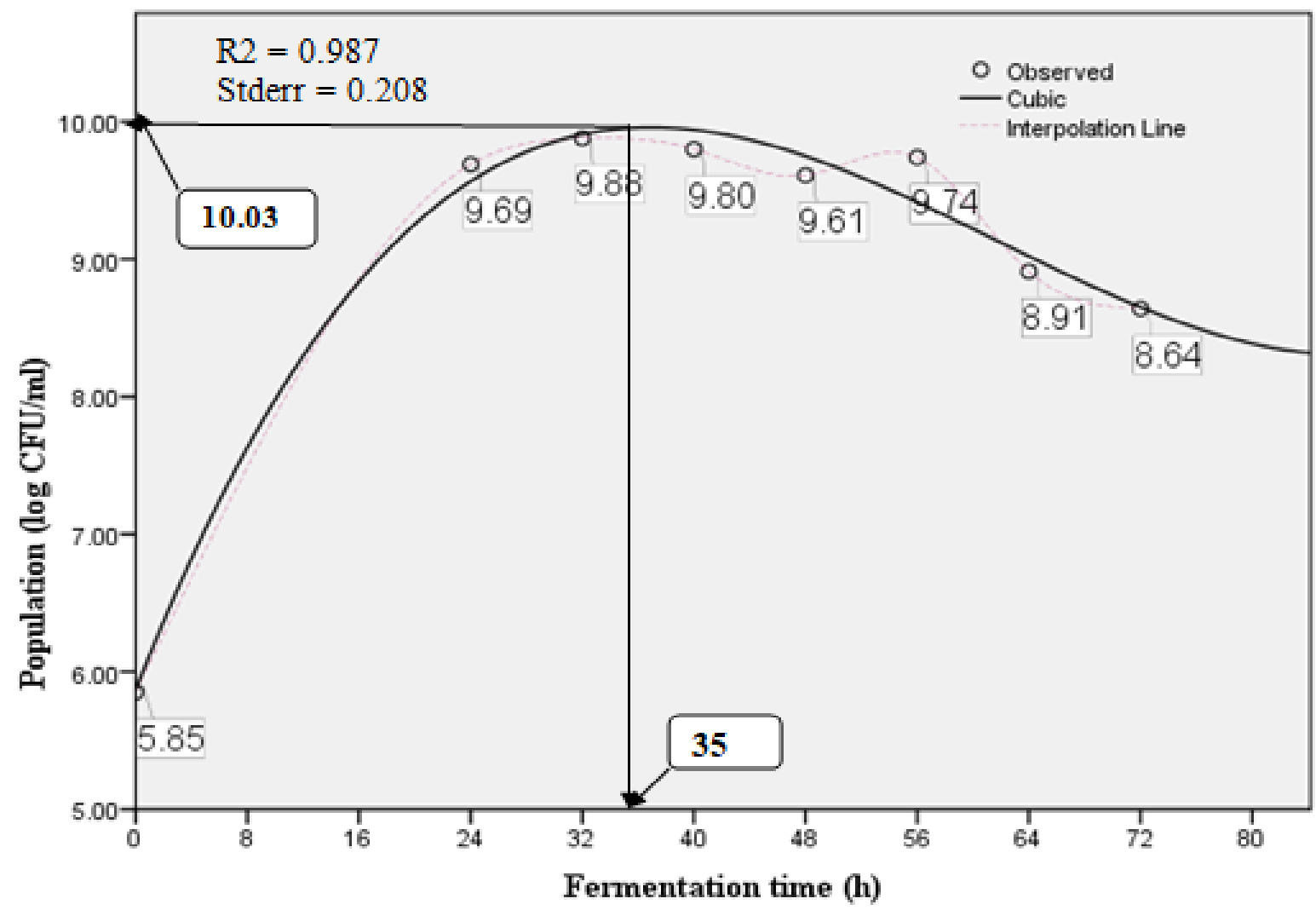


Fig.2 Effect of fermentation time on population of L. acidophilus MCC10307 in amla drink

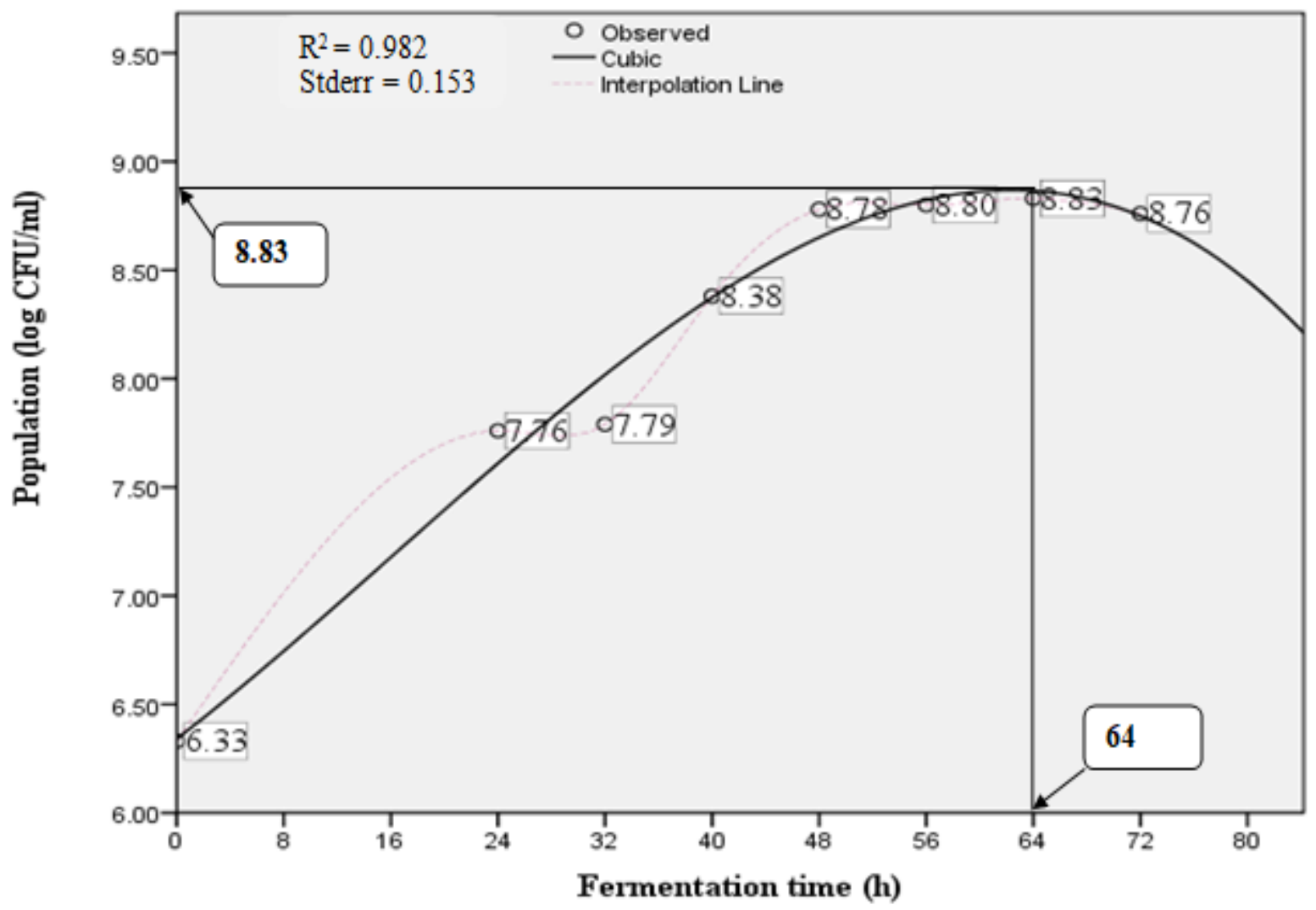

Fig.3 Total soluble solids of amla drink during fermentation

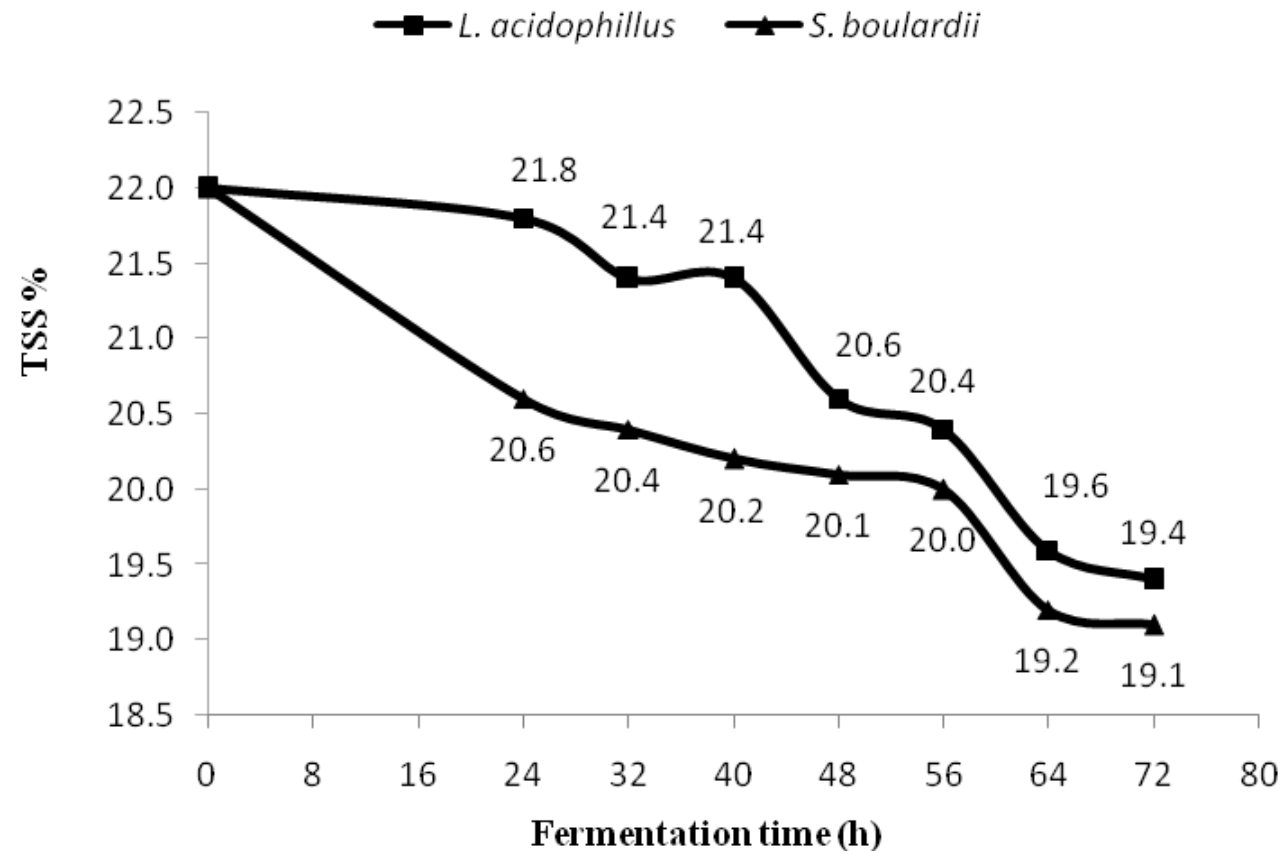


Fig.4 $\mathrm{pH}$ of amla drink during fermentation

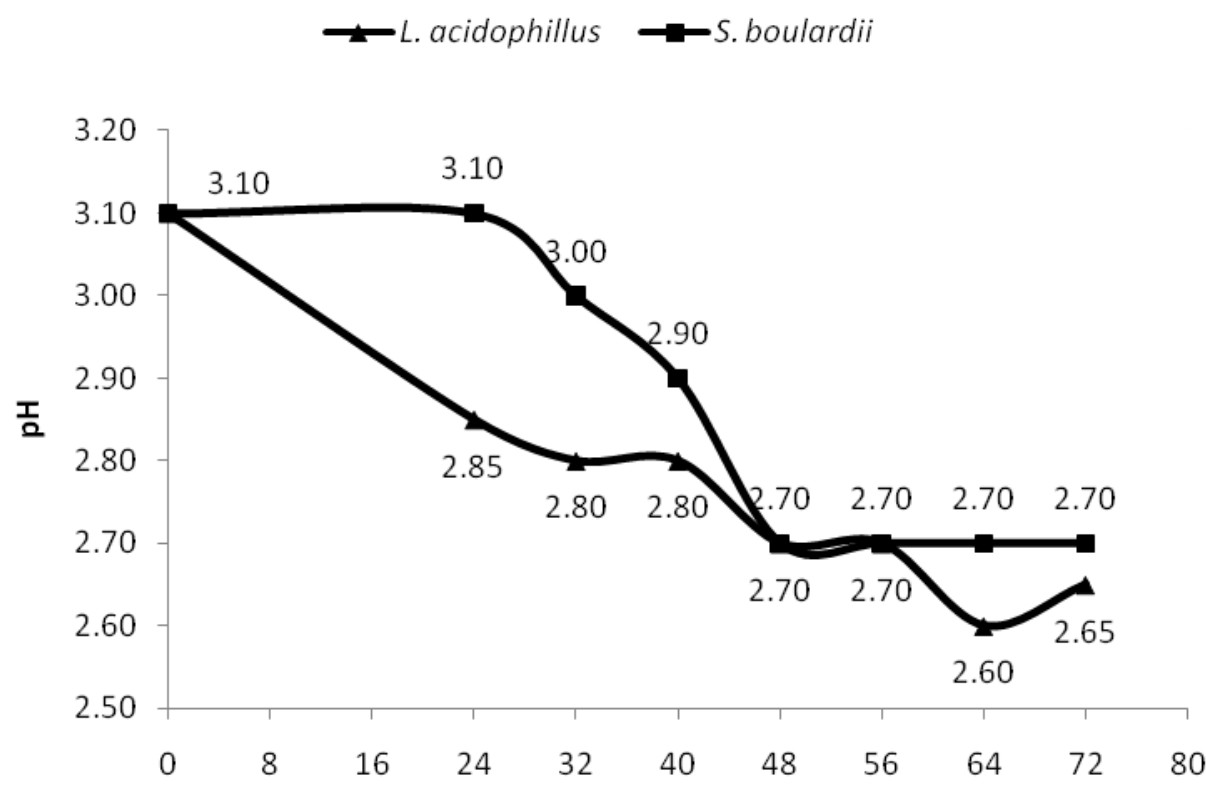

Fermentation time (h)

Change in $\mathrm{pH}$ with fermentation time in amla drink is shown and the data is presented in Figure 4. With the production of acid during fermentation by both the cultures, as expected initial $\mathrm{pH}$ of 3.1 of amla drink was gradually decreased. According to the literature studies, $\mathrm{pH}$ value of the fermented media significantly changed with fermentation time, substrate, and strain. $\mathrm{pH}$ value significantly affected further microorganism activity of the media (Steinkraus, 1992).

These organisms are grown in fruit drinks and as a result, acid and alcohol production occur and lower the $\mathrm{pH}$ rapidly to a point where competing organisms are no longer able to grow. Therefore, the most significant factor in growth limitation is probably the $\mathrm{pH}$ value after the certain time of fermentation. Prado et al., (2008) reported that Lactobacillus casei $D N-114$ 001, Lactobacillus rhamnosus $G G$ and Lactobacillus paracasei remained viable in orange $(\mathrm{pH} 3.65)$ and pineapple $(\mathrm{pH} 3.40)$ juices at the levels greater than $10^{7} \mathrm{CFU} / \mathrm{ml}$ and $10^{6} \mathrm{CFU} / \mathrm{ml}$.

\section{Acceptability of fermented amla drink}

Sensory scores for fermented amla drink by Saccharomyces boulardii CNCM 1-745 and Lactobacillus acidophilus MCC10307 upto their optimum fermentation time with unfermented fruit drink is presented in Table 2. Fifteen per cent unfermented amla drink was used as the control. The scores pertaining to sensory qualities of fermented drinks are significantly $(\mathrm{P} \leq 0.05)$ lower than the unfermented drinks and there were no significant $(\mathrm{P} \leq 0.05)$ differences between $S$. boulardii CNCM 1-745 fermentation and $L$. acidophilus MCC10307 fermentation on sensory properties. Hence the experiment drinks needed modification in sensory parameters. This may be due to the development of undesirable flavour and aroma during fermentation due to production of undesirable by-products such as alcohol. Unpleasant perfumery aromas, as well as sour and savoury flavours have been observed by Luckow et al., (2006) in orange drinks inoculated with Lactobacillus Plantarum and 
has been reported that the perceptible offflavors of probiotic orange drink, that often contribute to consumer dissatisfaction. These findings support the present study.

\section{Improvement action in order to enhance sensory quality of probiotic amla drinks}

In order to enhance the organoleptic properties while maintaining highest cell growth, some improvement action was carried out as follows,

Adjustment of initial $\mathrm{pH}$ of the drink to organism's optimum $\mathrm{pH}$ level.

Adjustment of total soluble solids of the fruit drink at $25^{\circ}$ Brix.

Lactobacillus acidophilus (nu-trish LA-5) organism was used to replace Lactobacillus acidophilus MCC10307 for fermentation.

Average $\mathrm{pH}$ of amla drink was 3.1 and at these $\mathrm{pH}$ level growth rates of organisms was less. Generally, optimum $\mathrm{pH}$ level for both organisms' is ranged from 3.5 to 5 . In order to increase the $\mathrm{pH}$ of amla drink to optimum level for organisms, calcium propionate, a buffer was used. Minimum optimum buffer concentration for maintaining $\mathrm{pH}$ of amla drink at 4.4 was 0.5 per cent and it was suitable to achieve desired $\mathrm{pH}$ range for optimum cell growth with better sensory parameters. This level was acceptable by the panel members and was within safe limits also. Total soluble solids were adjusted at $25^{\circ}$ Brix to increase $\mathrm{pH}$ and nutritional source for the growth of organisms while maintaining sweetness of drinks at acceptable levels. Lactobacillus acidophilus (nu-trish LA-5), a freeze dried ready-made culture with higher viability was needed. Amla drink adjusted for $\mathrm{pH}$ and TSS were inoculated with a $10 \%$ (v/v) of S. boulardii CNCM 1-745 and L. acidophilus (nu-trish LA-5) inoculums separately and incubated at $30^{\circ} \mathrm{C}$ for $3 \mathrm{hr}$ for fermentation. Since cultures are having high growth rate in this condition, the population was analyzed in order to confirm the significant growth of them in amla drink. All these improvement actions were used to bring down the fermentation time while maintaining highest cell count since probiotic fruit drinks with less fermentation period provide better organoleptic properties.

\section{Nutritive value of probiotic amla drink}

Ascorbic acid content and antioxidant potential of unfermented and fermented amla drinks is tabulated in Table 3. Ascorbic acid content of both fermented and unfermented amla drink ranged from 96-109 $\mu \mathrm{g} / \mathrm{ml}$ and there was no significant difference between fermented and unfermented amla drink. Similarly, antioxidant potential of both fermented and unfermented amla drink is 938 $\mu \mathrm{g} / \mathrm{ml}$ and there was no significant difference of antioxidant potential of fermented and unfermented amla drink proving that probiotication has maintained antioxidant potential of the developed drink.

Mishra et al., (2011) reported that the ascorbic acid content of the fresh amla fruit was $463 \mathrm{mg} / 100 \mathrm{~g}$. When the fruit was made into powder there was an increase in the vitamin $\mathrm{C}$ content. Freeze dried powder had the maximum vitamin $\mathrm{C}$ content a 5432.75 $\mathrm{mg} / 100 \mathrm{~g}$ whereas the sun dried amla powder contained the vitamin $\mathrm{C}$ as $3006.00 \mathrm{mg} / 100 \mathrm{~g}$. An investigation involving blends of anola and kinnow mandarin juice for their value addition to prepare a RTS beverage was carried out by Jain and Meena (2013). It had $27.92 \mathrm{mg} / 100 \mathrm{ml}$ of ascorbic acid content. The minimum vitamin $\mathrm{C}$ content of 85.47 $\mathrm{mg} / 100 \mathrm{~g}$ was reported in amla murabbas, whereas the maximum of $166.46 \mathrm{mg} / 100 \mathrm{~g}$ in the product was reported by Patel et al., (2013). Puranik et al., (2012) reported the 
DPPH per cent scavenging activity in the amla candy, bar and toffee. Fresh amla showed DPPH scavenging activity of 83.24 whereas candy $(42.77 \%)$ showed highest DPPH scavenging activity among the processed products and the toffee (18\%) showed the lowest value among all. The reason for low bioactive component retention in the toffee when compared to candy and bar was attributed to the heat processing. The free radical scavenging activity of the fresh amla fruit ranges from 80.3 per cent to 86.8 per cent (Prakash et al., 2012).

\section{Storage study of probiotic amla drink}

The data in Table 4 illustrates the effect of cold storage on viability of Saccharomyces boulardii CNCM 1-745 and Lactobacillus acidophilus (nu-trish LA-5) in fermented amla drink. Initial $\mathrm{pH}$ was adjusted to 4.4 by using a buffer. Total soluble solids were adjusted at $25^{\circ}$ Brix as well. After $3 \mathrm{hr}$ of fermentation, a superior population of both the organisms was observed. The initial total viable count of the drink was $10^{9}$ and $10^{10}$ $\mathrm{CFU} / \mathrm{ml}$, in case of Saccharomyces boulardii CNCM 1-745 and Lactobacillus acidophilus (nu-trish LA-5) respectively

Saccharomyces boulardii CNCM 1-745 grown at $30^{\circ} \mathrm{C}$ could survive for several weeks in the fermented amla at $4^{\circ} \mathrm{C}$ storage, while Lactobacillus acidophilus (nu-trish LA5) could survive for 12 days. During 30 days storage period, there was no significant change in population of Saccharomyces boulardii CNCM 1-745 upto 30 days and there was no significant change in population of Lactobacillu acidophilus (nu-trish LA-5) upto 12 days. However, after 12 days, Lactobacillus acidophilus (nu-trish LA-5) has lost its viability and there was no convenient cell growth after that. The viability of probioitic organisms is dependent on many factors, such as level of oxygen in products, oxygen permeation of the package, fermentation time and storage temperature (Soccol et al., 2007) and also it is affected by lactic acid produced during production and cold storage. Contrary to the study results, some researchers (Wang et al., 2002) have reported a decline in total viable count of Lactobacillus reuteri and Biofidobacterium bifidum of whey based probiotic beverage stored at $4 \pm 1^{\circ} \mathrm{C}$ and Lactobacillus acidophilus in commercial yoghurt during refrigerated storage.

Fermented (for 3 hours) amla drink by Saccharomyces boulardii CNCM 1-745 and Lactobacillus acidophilus (nu-trish LA-5) did not show sensory differences throughout the studied storage period for all sensory attribute with overall acceptability scores of 7.3 and 8.0 respectively. Storage studies of amla drink with Saccharomyces boulardii CNCM 1-745 was continued for 30 days while with Lactobacillus acidophilus (nu-trish LA-5) was discontinued after 12 days since loss of cell viability. With the consideration, both population and sensory quality, amla drink with Saccharomyces boulardii CNCM 1-745 can be stored at refrigerated conditions for 4 weeks while Lactobacillus acidophilus (nutrish LA-5) can be stored for 12 days.

These findings are in line with the findings of Kumar et al., (20013) who reported the changes in sensory attributes of whey based probiotic beverage. According to the researchers it did not show sensory differences for the first two weeks at refrigerated storage. But after the second week, difference was perceived in colour and flavour.

However, amla drink suffers from severe browning during storage, particularly at a higher temperature, which adversely affects the appearance and overall acceptability of juice (Bhattacherjee et al., 2011). 
Formulation of probiotic fruit drink using amla fruit was possible with Saccharomyces boulardii and required cell count, good sensory qualities having 30 days storage period was achieved in the present study. Formulation of probiotic fruit drinks using amla fruit was possible with Lactobacillus acidophilus with required cell count, good sensory qualities with 12 days storage period. These probiotic drinks as the best alternatives to dairy based probiotic products. Exploitation of antioxidant rich foods as a substrate for beneficial micro flora is achieved.

\section{References}

Amaley, S.H., Sapka, R.S., Sapka, V.S., Motghare, K.A., and Jangde, V.R. (2016). Fermentation Process for manufacturing of wine from Emblica officinalis fruits. International Journal of Advanced Research in Basic Engineering Sciences and Technology, $2,10$.

Anonymous. (2001). Health and nutritional properties of probiotics in food including powder milk with live lactic acid bacteria. Cordoba, Argentina: Food and Agriculture Organization of the United Nations and World Health Organization, Expert Consultation Report.

Baliga, M.S., Prabhu, A.N., Prabhu, D.A., Shivashankara, A.R., Abraham, A., and Palatty, P.L. (2013). Antidiabetic and cardio protective effects of Amla (Emblica officinalis) and its phytochemicals: Preclinical observations. Journal of Ethnopharmacology, 5, 583-600.

Benzie, I.F.F., and Strain, J.J. (1999). Ferric reducing/antioxidant power assay: Direct measure of total antioxidant activity of biological fluids and modified version for simultaneous measurement of total antioxidant power and ascorbic acid concentration. Methods in Enzymology, 299, 15-27.

Bhattacherjee, A.K., Tandon, D.K., Dikshit, A., and Kumar, S. (2011). Effect of pasteurisation temperature on quality of anola juice during storage. Journal of Food Science and Technology, 48(3), 269-273.

Charalampopoulos, D., Pandiella, S.S., and Webb, C. (2002). Growth studies of potentially probiotic lactic acid bacteria in cereal-based substrates. Journal of Microbiology, 92, 851-859.

Chiang, Y.W., Chye, F.Y., and Mohd, I.A. (2006) Microbial Diversity and proximate composition of Tapai, a Sabah's fermented beverage. Malaysian Journal of Microbiology, 2(1), 1-61.

Dandin, G. (2010) Therapeutic effect of fermented kokum juice. $\mathrm{PhD}$ thesis submitted to University of Agricultural Sciences, Bangalore.

Dimitrovski, D., Velickova, E., Langerholc, T., and Winkelhausen, E. (2015). Apple juice as a medium for fermentation by the probiotic Lactobacillus plantarum PCS 26 strain. Annals of Microbiology, 65, 2161-2170.

Duygu, A. (2004). Kinetic modelling of lactic acid production from whey. Izmir Yuksek Teknoloji Enstitusu, 2, 13-27.

Ganzle, M.G., Vermeulen, N., and Vogel, R.F. (2007). Traditional solid-state fermentations of plant raw materials application, nutritional significance and future prospects. Food Microbiology, 24:128.

Gopalan, G., Goldstein, L., Klingenstein, K., Sicher, C., Blake, C., and Mckay, M. M., 2010, Engaging families into child mental health treatment: Updates and special considerations. Journal of the Canadian Academy of Child and Adolescent Psychiatry, 19(3), 182-196. 
Jain, S.K., and Khurdiya, D. S. (2004). Vitamin $\mathrm{C}$ enrichment of fruit juice based ready to serve beverages through blending of Indian gooseberry (Emblica officinalis). Plant Foods for Human Nutrition, 59(2), 63-66.

Jain, S.K., and Meena, P. (2013). Studies on the standardization of blended aonlakinnow mandarin RTS beverage. The Asian Journal of Horticulture, 8(2), 605-608.

Kumar, R.S., Ray, R.C., Paul, P.K., and Suresh, C.P. (2013). Development and storage studies of therapeutic ready to serve (RTS) made from blend of aloevera, anola and ginger juice. Journal of Food Processing and Technology, 4(6), 4-6.

Luckow, T., Sheehan, V., Fitzgerald, G., and Delahunty, C. (2006). Exposure, health information and flavoured masking strategies for improving the sensory quality of probiotic juice. Appetite, 47, 315-325.

Matsuzaki, T., and CHIN, J. (2000). Modulating immune responses with probiotic bacteria. Immunology and Cell Biology, 78: 67-73.

Mishra, P., Verma, M., Mishra, V., and Rai, G.K. (2011). Studies on development of ready to eat amla (Emblica officinalis) chutney and its preservation by using class one preserevatives. American Journal of Food Technology, 6(3), 244252.

Muruganandam, A.V., Kumar, V., and Bhattacharya, S.K. (2002). Effect of poly herbal formulation, EuMil, on chronic stress-induced homeostatic perturbations in rats. Indian Journal of Experimental Biology, 40(10), 1151-60.

Nosal, O. G., Mokry, J., and Hasan, K.M. (2003). Antitussive activity of the fruit extract of Emblica officinalis Gaertn, (Euphorbiaceae). Phytomedicine, 10, 583-9.
Oxman, T., Shapira, M., Klein, R., Avazov, N., and Rabinowitz, B. (2001). Oral administration of Lactobacillus induces cardioprotection. Journal of Alternative and Complementary Medicine, 7(4), 345-354.

Pathak, R. K., Pandey, D., Mishra, A. K., and Mishra, M. (2003). Aonla for health and Prosperity. Extension Literature 18, CISH, Lucknow.

Pereira, A.L.F., Maciel, T.C., and Rodrigues, S. (2011). Probiotic beverage from cashew apple juice fermented with Lactobacillus casei. Food Res. Int., 44, 1276-1283.

Prado, F.C., Parada, J.L., Pandey, A., and Soccol, C.R. (2008). Trends in nondairy probiotic beverages. Food Research International, 41, 111-123.

Prakash, D., Upadhyay, G., Gupta, C., Pushpagandan, P., and Singh, K.K. (2012). Antioxidant and free radical scavenging activities of some promising wild edible fruits. International Food Research Journal, 19(3), 1109-1116.

Priya, M.D., and Khatkar, B.S. (2012). Effect of processing methods on keeping quality of aonla (Emblica officinalis Gaertn.) preserve. International Journal of Food Research, 20(2), 617-622.

Priyanka, (2014). Evaluation of commercial amla products. M.Sc. thesis submitted to University of Agricultural Sciences, Bangalore.

Puranik, V., Mishra, V., Yadav, N., and Rai, G. K. (2012). Bioactive components retention in processed Indian gooseberry products. Journal of Food Processing and Technology, 3(12), 1- 3.

Reid, G., and Bruce, A.W. (2001). Selection of Lactobacillus strains for urogenital probiotic applications. Journal of Infectious Diseases, 183, 77-80.

Sadasivam, S., and Manickam, A. (1997). Biochemical methods. New age 
international (Pvt.) ltd. Pub. 2 nd edition.

Santoshkumar, J., Manjunath, S., and Pranavkumar, M.S., (2013). A study of antihyperlipidemia, hypolipedimic and anti-atherogenic activity of fruit of Emblica officinalis (amla) in high fat fed Albino Rats. International Journal of Medical Research et Health Sciences, 2(1), 70-77.

Sharma, S.K., James, B., Joseph, A.J.M., and Christina, J. (2004). Evaluation of antipyretic and analgesic activity of Emblica officinalis Gaertn. Journal of Ethno pharmacology, 95, 83-5.

Soccol, C.R., Prado, F.C., and Parada, J.L. (2007). Technological process to produce a coconut fermented beverage with probiotic properties. BR patent PI0703244-7.

Srivasuki, K.P. (2012). Nutritional and health care benefits of Amla. Journal of Pharmaceutical Sciences, 3(2), 141-51.

Steinkraus, K.H. (1992). Applications of biotechnology to traditional fermented foods. Washington, D.C.: National Academy Pres, 43-51.

Tuorila, H., Huotilainen, A., Lahteenmaki, L., Ollila, S., Tuomi- nurmi, S., and Urala, N. (2008). Comparison of affective rating scales and their relationship to variables reflecting food consumption. Food Quality and Preference, 19, 5161.

Vasudha, S., and Mishra, H.N. (2013). Nondairy probiotic beverages. International Journal of Food Research, 20, 7-15.

Wang, Y.C., Yu, R.C., and Chou, C.C. (2002). Growth and survival of Bifidobacteria and lactic acid bacteria during the fermentation and storage of cultured soymilk drinks, Food Microbiology, 19, 501-508.

Zhang, L.Z., Zhao, W.H., Guo, Y.J., Tu, G.Z., Lin, S., and XIN. L.G. (2003). Studies on chemical constituents in fruits of Tibetan medicine Phyllanthus emblica. Zhurnal Prikl Him, 28(10), 940-3.

\section{How to cite this article:}

Namesha Dulari Wijemanna and Usha Ravindra. 2018. Amla as a Potential Substrate for Production of Probiotic Drink. Int.J.Curr.Microbiol.App.Sci. 7(09): 2743-2756. doi: https://doi.org/10.20546/ijcmas.2018.709.341 